\title{
PERBANDINGAN KADAR LOW DENSITY LIPOPROTEIN CHOLESTEROL( LDL-C) PADA PEROKOK DAN BUKAN PEROKOK
}

\author{
${ }^{1}$ Patrix Kaparang \\ ${ }^{2}$ Sunny Wangko \\ ${ }^{2}$ Marie M. Kaseke
}

\author{
1 Kandidat Skripsi Fakultas Kedokteran Universitas Sam Ratulangi Manado \\ 2 Bagian Anatomi-Histologi Fakultas Kedokteran Universitas Sam Ratulangi \\ Email: atis_patrix@yahoo.com
}

\begin{abstract}
Smoking in many forms is the main risks factor of atherosclerotic process and coronay heart diseases. Cigarette smoking results in increases of total cholesterol, triglyserida, LDL-C, and VLDL-C, and a decrease of HDL-C blood levels. The aim of this study was to compare the LDL-C levels of smokers with non-smokers males. This was an observational study with a cross sectional design. This study was done in the Faculty of Medicine, University of Sam Ratulangi Manado from November to Desember 2012, by using a purposive sampling technique. There were 60 smoker students and non-smoker students of semester 7 Faculty of Medicine, University of Sam Ratulangi, Manado who fulfilled the inclulsion criteria. Data were taken from questionnaires and examinations of LDL-C levels. LDL-C levels were analyzed by using the SPSS version 20 . The results showed that the analysis of the comparison of LDL-C levels of the smoker students' with of the nonsmokers'students had a P-value 0.911. Conclusion: There was no significant difference of the LDL-C levels between smokers and non-smokers.
\end{abstract}

Keywords: atherosclerotic, LDL-C level, smoker, non-smoker

\begin{abstract}
Abstrak: Merokok dalam berbagai bentuk merupakan faktor risiko utama aterosklerosis dan penyakit jantung koroner. Rokok menyebabkan peningkatan konsentrasi serum kolesterol total, trigliserida, LDL-C, VLDL-C dan penurunan HDL-C. LDL-C yang berlebihan dalam plasma menginduksi terjadinya aterosklerosis.Penelitian ini bertujuan untuk membandingkan kadar LDL-C pada laki-laki perokok dengan yang bukan perokok. Penelitian ini bersifat observasional dengan desain penelitian potong lintang. Penelitian dilakukan di Fakultas Kedokteran Universitas Sam Ratulangi Manado pada bulan November-Desember 2012. Teknik pengambilan sampel menggunakan purposive sampling. Sampel diperoleh sebanyak 60 orang mahasiswa kaki-laki semester 7 Fakultas Kedokteran Unsrat tahun ajaran 2012 yang perokok dan bukan perokok, yang memenuhi criteria inklusi. Data didapatkan dari kuesioner dan pemeriksaan kadar LDL-C serum. Kadar LDL-C dianalisis dengan menggunakan SPSS versi 20. Hasil analisis perbandingan kadar LDL-C antara mahasiswa perokok dan bukan perokok menunjukkan nilai $P=0,911$. Simpulan: Tidak terdapat perbedaan bermakna antara kadar LDL-C antara perokok dan bukan perokok.
\end{abstract}

Kata kunci: aterosklerosis,kadar LDL-C, perokok.

Merokok merupakan penyebab utama kematian dan diperkiraan saat ini di seluruh dunia telah memrediksi bahwa pada tahun 2030 merokok akan menyebabkan 10 juta kematian per tahun. ${ }^{1}$ Merokok memiliki dampak yang besar bagi kesehatan. Di negara berkembang produk-produk rokok mudah diakses dan sangat murah. Hal ini dengan mudah memengaruhi para dewasa muda sehingga menyebabkan penggunaan 
jangka panjang dan kecanduan untuk merokok. ${ }^{2}$

Secara global angka kejadian merokok lebih banyak pada laki-laki dibandingkan perempuan. Lebih dari lima juta orang per tahun dan kebanyakan laki-laki meninggal karena merokok, dan diperkirakan pada tahun 2030 akan melebihi delapan juta orang per tahun dengan angka kematian mencapai $80 \%{ }^{3}$ Merokok merupakan salah satu faktor risiko terpenting untuk kematian dini di negara maju. WHO (2004) memmerkirakan bahwa saat ini sekitar lima juta kematian per tahun di seluruh dunia disebabkan karena merokok. ${ }^{4}$

Jumlah perokok akan meningkat seiring dengan pertambahan penduduk dunia. Meningkatnya jumlah perokok berisiko terhadap beberapa penyakit kanker (terutama kanker paru-paru), penyakit jantung koroner, infark serebri, emfisema, dan beberapa penyakit akut serta kronis. Di Indonesia jumlah perokok meningkat seiring dengan pertambahan populasi penduduk. Berdasarkan jumlah dan hasil survei kesehatan rumah tangga Indonesia, terdapat peningkatan risiko berbagai penyakit pada kalangan yang merokok. ${ }^{5}$

Rokok mengandung lebih dari 6.000 senyawa, dan asap rokok (partikel dan gas) mengandung lebih dari 4.000 bahan kimia serta senyawa yang bersifat karsinogenik. Zat kimia dalam rokok berperan penting dalam terjadinya aterosklerosis, karsinogenis, serta penyakit saluran pernapasan dan kardiovaskuler. ${ }^{6}$ Nikotin merupakan salah satu unsur utama dalam rokok. Nikotin menyebabkan peningkatan kadar trigliserida, kolesterol, dan VLDL, serta penurunan kadar HDL. Konsumsi nikotin jangka panjang dapat meningkatkan kolesterol LDL dan penurunan kolesterol HDL. ${ }^{7}$

Terdapat bukti menunjukkan bahwa merokok berhubungan dengan peningkatan produksi radikal bebas dan deplesi antioksidan. Radikal bebas menyebabkan kerusakan oksidatif pada beberapa makromolekul seperti lipid, protein, dan DNA, sehingga berperan penting dalam beberapa penyakit kronis seperti aterosklerosis dan kanker. ${ }^{8}$
Merokok dalam berbagai bentuk merupakan faktor risiko utama untuk aterosklerosis dan penyakit jantung koroner. Rokok menyebabkan peningkatan konsentrasi serum kolesterol total, trigliserida, LDL-C, VLDL-C dan penurunan HDL-C. Berbagai mekanisme menyebabkan perubahan lipid oleh zat yang terkandung dalam rokok yaitu nikotin pada seorang perokok. ${ }^{9}$ LDL-C yang berlebihan dalam plasma memegang peranan penting dalam meng-induksi terjadinya aterosklerosis. ${ }^{10}$

Penelitian Neki (2002) menunjukkan bahwa kadar LDL-C lebih tinggi pada perokok dibandingkan yang bukan perokok. ${ }^{9}$ Hasil penelitian Neki berbeda dengan penelitian di Jepang tahun 2007 yang menunjukkan bahwa tidak terdapat perbedaan bermakna kadar LDL-C perokok dan bukan perokok. ${ }^{6}$ Berdasarkan bahasan di atas, peneliti tertarik untuk membandingkan kadar LDL-C pada perokok dan bukan perokok, khususnya kalangan mahasiswa semester 7 tahun ajaran 2012 Fakultas Kedokteran Universitas Sam Ratulangi Manado.

\section{METODE PENELITIAN}

Metode penelitian ini bersifat observasional dengan desain penelitian potong lintang. Penelitian dilakukan di Fakultas Kedokteran Universitas Sam Ratulangi Manado pada bulan November-Desember 2012. Populasi penelitian ialah seluruh mahasiswa laki-laki Fakultas Kedokteran Universitas Sam Ratulangi Manado Semester 7 tahun ajaran 2012 yang berjumlah 140 orang. Teknik pengambilan sampel dengan menggunakan purposive sampling. Sampel yang diperoleh berjumlah 60 orang yang memenuhi kriteria inklusi. Setelah mendapatkan persetujuan melalui informed consent, sampel diperiksa kadar LDL-C dengan metode homogency LDL-C yang menggunakan reaksi enzimatik.

Sebelum penelitian dilakukan, subyek penelitian diberikan penjelasan mengenai pengambilan darah melalui vena mediana cubiti. Data yang diperoleh diolah dengan menggunakan uji perbandingan t (unpaired t-test). 


\section{HASIL PENELITIAN}

Penelitian ini dilakukan pada mahasiswa laki-laki Fakultas Kedokteran UNSRAT angkatan 2009 yang telah bersedia berpartisipasi dalam penelitian. Jumlah keseluruhan mahasiswa laki-laki semester 7 tahun ajaran 2012 ialah 140 orang. Sampel yang memenuhi kriteria inklusi yaitu mahasiswa laki-laki 30 yang merokok dan 30 yang tidak merokok.

\section{Distribusi subjek berdasarkan usia}

Penelitian ini bertujuan untuk mendapatkan perbandingan kadar LDL-C pada perokok dan bukan perokok, khususnya pada mahasiswa dengan usia rata-rata 19-23 tahun. Kedua kelompok ini sebanding untuk jenis kelamin namun untuk usia tidak sebanding (Tabel 1).

Tabel 1. Kelompok responden berdasarkan usia

\begin{tabular}{cccc}
\hline & \multicolumn{2}{c}{$\begin{array}{c}\text { Kelompok } \\
\text { responden }\end{array}$} & \\
\cline { 2 - 3 } Usia & Total \\
\cline { 2 - 3 } & Perokok & $\begin{array}{c}\text { Bukan } \\
\text { Perokok }\end{array}$ & \\
\hline 19 Tahun & 2 & 2 & 4 \\
20 Tahun & 5 & 10 & 15 \\
21 Tahun & 11 & 14 & 25 \\
22 Tahun & 9 & 4 & 13 \\
23 Tahun & 3 & 0 & 3 \\
Total & 30 & 30 & 60 \\
\hline
\end{tabular}

Jumlah subjek dalam penelitian sebanyak 60 orang dengan persentase terbesar usia 21 tahun sebanyak 25 orang (41\%) dan terkecil pada usia 23 tahun dengan jumlah 3 orang (5\%) (Tabel 1).

\section{Karakteristik kadar LDL-C}

Karakteristik kadar LDL-C darah pada laki-laki perokok dapat dilihat pada Tabel 2. Pada 30 subjek penelitian yang perokok nilai rata-rata kadar LDL-C darah 108,37 (mg/dL) dengan standar deviasi 31,447, nilai maksimum 173 (mg/dL), dan nilai minimum 50 (mg/dL).
Tabel 2. Karakteristik kadar LDL-C darah pada laki-laki perokok

\begin{tabular}{cc}
\hline Klasifikasi & $\begin{array}{c}\text { Kadar LDL-C darah } \\
\text { (mg/dL) }\end{array}$ \\
\hline Rata-rata & 108,37 \\
Standar deviasi & 31,447 \\
Nilai maksimum & 173 \\
Nilai minimum & 50 \\
\hline
\end{tabular}

Karakteristik kadar LDL-C darah pada laki-laki yang bukan perokok dapat dilihat pada Tabel 3.

Tabel 3. Karakteristik kadar LDL-C darah pada laki-laki bukan perokok

\begin{tabular}{cc}
\hline Klasifikasi & $\begin{array}{c}\text { Kadar LDL-C darah } \\
\text { (mg/dL) }\end{array}$ \\
\hline Rata-rata & 104,90 \\
Standar deviasi & 29,277 \\
Nilai maksimum & 173 \\
Nilai minimum & 50 \\
\hline
\end{tabular}

Pada 30 subjek penelitian laki-laki yang bukan perokok nilai rata-rata kadar LDL-C darah 104,90 (mg/dL) dengan standar deviasi 29,277, nilai maksimum 173 (mg/dL), dan nilai minimum 50 (mg/dL).

\section{Pengujian hipotesis}

Hasil perhitungan diperoleh dengan menggunakan t-test unpaired (Tabel 4).

Tabel 4. Hasil uji perbandingan t-test unpaired.

\begin{tabular}{llll}
\hline & $\begin{array}{l}\text { Subyek penelitian } \\
\text { Rerata }\end{array}$ & n & P value \\
\cline { 2 - 3 } Kadar & Perokok & 30 & \\
LDL-C & $108,37 \pm 31,447$ & & 0,911 \\
& $\begin{array}{l}\text { Bukan perokok } \\
104,90 \pm 29,277\end{array}$ & & \\
& 104,90 & \\
\hline
\end{tabular}

Rerata kadar LDL-C lebih tinggi pada perokok (108,37 \pm 31,447 mg/dl) dibandingkan yang bukan perokok (104,90 \pm 29,277 mg/dL), tetapi peningkatan tersebut tidak bermakna secara statistik karena nilai $P>\alpha \quad(\alpha=0,05)$. 


\section{BAHASAN}

Dalam berbagai bentuk merokok merupakan faktor risiko utama untuk aterosklerosis dan penyakit jantung koroner. Rokok menyebabkan peningkatan konsentrasi serum kolesterol total, trigliserida, LDL-C, VLDL-C dan penurunan HDL-C. Berbagai mekanisme menyebabkan perubahan lipid oleh karena merokok. ${ }^{9}$ Angka kejadian merokok lebih banyak pada laki-laki dibandingkan perempuan. Lebih dari lima juta orang per tahun dan kebanyakan laki-laki meninggal karena merokok. $^{3}$

Rokok mengandung lebih dari 6.000 senyawa, dan asap rokok (partikel dan gas) mengandung lebih dari 4.000 bahan kimia serta senyawa yang bersifat karsinogenik. ${ }^{6}$ Bahan-bahan dalam rokok sangat bervariasi dan membahayakan. Nikotin merupakan unsur utama rokok yang mengandung senyawa anorganik dan sangat beracun. Zat-zat seperti amonia, karbon monoksida, formaldehida, serta arsenik juga dapat ditemukan dalam rokok. Merokok menyebabkan sentakan cepat nikotin ke otak. Nikotin diserap melalui kulit serta lapisan mukosa mulut dan hidung melalui selaput paru-paru ketika sedang bernapas. Nikotin mencapai otak dalam waktu sepuluh detik melalui aliran darah. ${ }^{11}$

Neki NS (2002) ${ }^{9}$ menunjukkan bahwa kadar LDL-C lebih tinggi pada perokok dibandingkan yang bukan perokok. Dalam penelitiannya, untuk peningkatan LDL-C pada perokok sangat tergantung dari jumlah rokok yang dihisap per hari. Pada penelitian ini tidak terdapat perbedaan bermakna antatra kadar LDL-C perokok dan bukan perokok, yang berbeda dengan hasil penelitian Neki.

Hasil penelitian ini memperlihatkan perbedaan yang tidak bermakna secara statistic. Hal ini mungkin disebabkan karena umumnya subjek penelitian rata-rata masih termasuk perokok ringan dengan usia 17-23 tahun. Penelitian ini serupa dengan penelitian yang dilakukan Raya $\mathrm{K}$ (2009) ${ }^{12}$ dimana diperoleh tidak terdapat perbedaan bermakna antara perokok dan bukan perokok karena peningkatan kadar LDL-C pada perokok sangat tergantung dari jumlah rokok yang dihisap. ${ }^{12}$

Sampel yang didapatkan pada penelitian ini yaitu usia muda antara 19-23 tahun dan perokok kebanyakan merupakan perokok ringan yang mengonsumsi rokok 1-10 batang per hari. Lamanya merokok pada sampel yang didapatkan kebanyakan tidak lebih dari 5 tahun, jadi belum tergolong perokok kronis. Penyebab peningkatan LDL-C juga multifaktorial dimana terdapat faktor lain yang dapat memicu peningkatan LDL-C selain mengonsumsi rokok.

Penelitian ini memiliki keterbatasan dimana sampel pada penelitian ini tidak terisolasi. Sampel pada penelitian ini ialah mahasiswa dan kebanyakan perokok sosial yaitu hanya merokok di saat berkumpul dalam suatu pergaulan atau komunitas tertentu.

Penelitian-penelitian yang dilakukan sebelumnya mendapatkan hasil bahwa untuk melihat perbedaan yang bermakna kadar LDL-C antara perokok dan bukan perokok sangat tergantung dari banyaknya sampel, jumlah rokok yang dihisap oleh perokok, dan lamanya merokok. Sama halnya dengan penelitian ini, hasil yang didapatkan tidak memperlihatkan perbedaan bermakna secara statistik antara kadar LDL-C darah pada laki-laki yang merokok dan tidak merokok di kalangan mahasiswa semester 7 tahun ajaran 2012 Fakultas Kedokteran Universitas Sam Ratulangi Manado. Subyek penelitian yang perokok mempunyai kadar LDL-C yang rata-rata hampir sama dengan yang bukan perokok. Untuk mendapatkan hasil perbandingan yang bermakna antara kadar LDL-C antara perokok dan bukan perokok perlu diperhatikan jumlah rokok yang dihisap tiap hari oleh seorang perokok.

\section{SIMPULAN}

Berdasarkan hasil penelitian ini dapat disimpulkan kadar LDL-C pada perokok dan bukan perokok tidak berbeda seacara bermakna walaupun rerata kadar LDL-C 
pada perokok sedikit lebih tinggi dibandingkan bukan perokok.

\section{UCAPAN TERIMA KASIH}

Ucapan terima kasih ditujukan kepada dr. Sonny J. R. Kalangi, MBiomed, PA dan dr. Shane H. R. Ticoalu, Mkes, AIFO selaku penguji skripsi serta kepada semua pihak baik yang secara langsung dan tidak langsung telah menumbuhkan ide dan gagasan pada penulis.

\section{DAFTAR PUSTAKA}

1. Eliasson B, Hjalmarson A, Kruse E, Landfeldt B, Westin A. Effect of smoking reduction and cessation on cardiovascular risk factors. Nicotine \& Tobacco Research. 2001;3:249-55.

2. WHO. Gender, Health and Tobacco. Geneva. World Health Organization, 2011.

3. Chiddarwar V, Jain J, Singhania S. Short term impact of smoking on cardiovascular functioning in adults from industrial town in Western Maharashtra, India. Int J Pharm Biomed Sci. 2012;3(4):220-3.

4. Baumert J, Ladwig K.H, Ruf E, Meisinger C, Döring A, Wichmann E. Determinants of heavy cigarette smoking. Augsburg Surveys. Nicotine \& Tobacco Research. 2010;1220-27.

5. Sutrisna B, Surtidewi L, Jusuf A, Hudoyo A, Kusmana D, Setianto B, et al.
Estimating the Annual Cost of SmokingRelated Diseases in Indonesia. Media Medika Indonesia. Fakultas Kedokteran Universitas Diponegoro dan Ikatan Dokter Indonesia. Jawa Tengah, 2009.

6. Urahama N, Iguchi $G$, Shimizu $M$, Fujihira K, Kobayashi S, Baba $H$. Smoking and small dense low-density lipoprotein particles: Cross-sectional study Norinaga Baba. Nicotine \& Tobacco Research. 2008:1391-95.

7. Zamir M, Akbari A, Bhatti MS, Shakoor M. Lipid profile in smoking. Department of Biochemistry Allama Iqbal Medical College Lahore. JAMC:2000.

8. Imge B. Short-term effects of smoking cessation on blood antioxidant parameters and paraoxonase activity in healthy asymptomatic long-term cigarette smokers. Ankara University School of Medicine, Department of Biochemistry, 2005.

9. Neki NS. Lipid profile in chronic smokers - A clinical study. JIACM. 2002;3(1):51-4.

10. Robbins, Cotran, Kumar. Buku Ajar Patologi Robbins (Edisi 7). Jakarta: EGC, 2007: p. 374-7.

11. Wagner HL, Triggle D. Nicotine. The health effects of nicotine and smoking. Chelsea House Publishers, 2003.

12. Bayati A, Raya K. Cigarette smoking and the accompanied alterations in lipid profile in a group of students in Al-Mustansiriyah University. National Journal of Chemistry. 2009:521-27. 